\title{
High variability of dung beetle diversity patterns at four mountains of the trans-Mexican volcanic belt
}

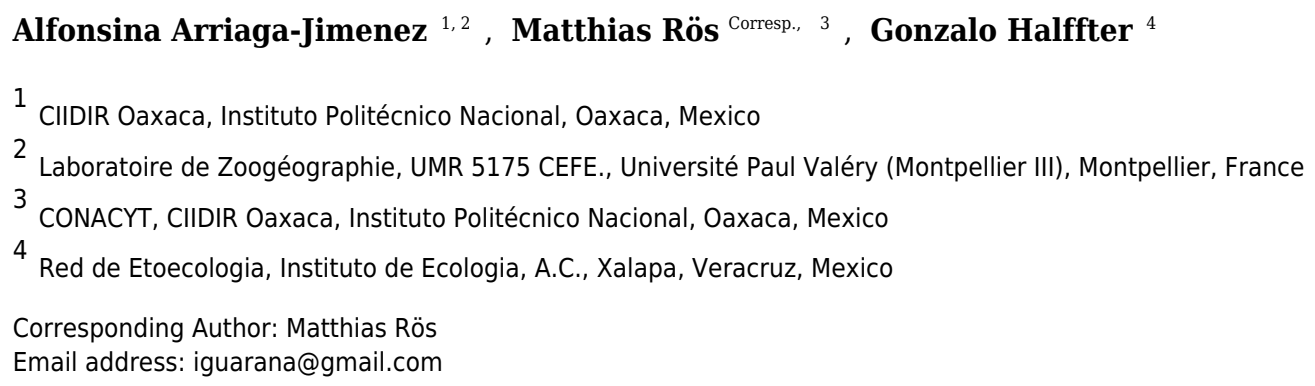

Insect diversity patterns of high mountain ecosystems remain poorly studied in the tropics. Sampling dung beetles of the subfamilies Aphodiinae, Scarabaeinae, and Geotrupinae was carried out at four volcanoes in the Trans-Mexican Volcanic Belt (TMVB) in the Mexican Transition Zone at 2700 and $3400 \mathrm{MASL}$, and on the windward and leeward sides. Sampling units represented a forest-shrubland-pasture (FSP) mosaic typical of this mountain region. 3430 individuals of 29 dung beetle species were collected. Diversity, abundance and compositional similarity displayed a high variability at all scales; elevation, cardinal direction or FSP mosaics did not show any patterns of higher or lower values of those measures. The four mountains were different regarding dispersion patterns and taxonomic groups, both for species and individuals. Onthophagus chevrolati dominated all four mountains with an overall relative abundance of $63 \%$. Compositional similarity (CS) was not related to distance among mountains, but when $O$. chevrolati was excluded from the analysis, CS values based on species abundance decreased with increasing distance. Speciation, dispersion and environmental instability are suggested as the main drivers of high mountain diversity patterns, acting together at different spatial and temporal scales. Three species new to science were collected ( $>10 \%$ of all species sampled). These discoveries may indicate that speciation rate is high among these volcanoes-a hypothesis that is also supported by the elevated number of collected species with a restricted montane distribution. Dispersion is an important factor in driving species composition, although naturally limited between high mountains; horizontal colonization events at different time scales may best explain the observed species composition in the TMVB, complemented by vertical colonization events to a lesser extent. Environmental instability may be the main factor causing the high variability of diversity and abundance patterns found during sampling. Together, we interpret these results as indicating that species richness and composition in the high mountains of the TMVB may be driven by 
biogeographical history while variability in diversity is determined by ecological factors. We argue that current conservation strategies do not focus sufficiently on protecting high mountain fauna, and that there is a need for developing and applying new conservation concepts that take into account the high spatial and temporal variability of this system. 
1 High variability of dung beetle diversity patterns at four mountains of the trans-Mexican volcanic belt

2 ALFONSINA ARRIAGA-JIMÉNEZ ${ }^{1,2}$, MATTHIAS RÖS $^{*}{ }^{3}$, GONZALO HALFFTER $^{4}$

$3 \quad{ }^{1}$ CIIDIR Oaxaca, Instituto Politécnico Nacional, Mexico

$4 \quad$ 'Laboratoire de Zoogéographie, UMR 5175 CEFE., Université Paul-Valéry (Montpellier III), Montpellier,

5 France

$6 \quad{ }^{3}$ CONACYT, CIIDIR Oaxaca, Instituto Politécnico Nacional, Mexico

$7 \quad{ }^{4}$ Red de Ecoetología, Instituto de Ecología, A.C., Xalapa, Veracruz, Mexico.

8 *E-mail: iguarana@gmail.com

\section{Abstract}

10 Insect diversity patterns of high mountain ecosystems remain poorly studied in the tropics. Sampling

11 dung beetles of the subfamilies Aphodiinae, Scarabaeinae, and Geotrupinae was carried out at four

12 volcanoes in the Trans-Mexican Volcanic Belt (TMVB) in the Mexican Transition Zone at 2700 and 3400

13 MASL, and on the windward and leeward sides. Sampling units represented a forest-shrubland-pasture

14 (FSP) mosaic typical of this mountain region. 3430 individuals of 29 dung beetle species were collected.

15 Diversity, abundance and compositional similarity displayed a high variability at all scales; elevation,

16 cardinal direction or FSP mosaics did not show any patterns of higher or lower values of those measures.

17 The four mountains were different regarding dispersion patterns and taxonomic groups, both for species

18 and individuals. Onthophagus chevrolati dominated all four mountains with an overall relative abundance

19 of $63 \%$. Compositional similarity (CS) was not related to distance among mountains, but when 0 .

20 chevrolati was excluded from the analysis, CS values based on species abundance decreased with

21 increasing distance. Speciation, dispersion and environmental instability are suggested as the main

22 drivers of high mountain diversity patterns, acting together at different spatial and temporal scales. Three

23 species new to science were collected ( $>10 \%$ of all species sampled). These discoveries may indicate that

24 speciation rate is high among these volcanoes-a hypothesis that is also supported by the elevated 
25 number of collected species with a restricted montane distribution. Dispersion is an important factor in

26 driving species composition, although naturally limited between high mountains; horizontal colonization

27 events at different time scales may best explain the observed species composition in the TMVB,

28 complemented by vertical colonization events to a lesser extent. Environmental instability may be the

29 main factor causing the high variability of diversity and abundance patterns found during sampling.

30 Together, we interpret these results as indicating that species richness and composition in the high

31 mountains of the TMVB may be driven by biogeographical history while variability in diversity is

32 determined by ecological factors. We argue that current conservation strategies do not focus sufficiently

33 on protecting high mountain fauna and that there is a need for developing and applying new

34 conservation concepts that take into account the high spatial and temporal variability of this system.

\section{Introduction}

36 The importance of studying high mountain ecosystems in order to understand biodiversity patterns and

37 evolutionary processes is widely recognized (Körner, 2000; Schmitt, 2009). Mountain tops have different

38 ecological conditions from their surrounding lowlands, and interconnection of their biota is less than in

39 other ecosystems. Vertical colonization (highland assemblages composed by species phylogenetically

40 related with those inhabiting lowlands) and horizontal colonization (colonization of highland assemblages

41 by lineages with a different evolutionary history and origin than those occupying lowlands), as well as

42 speciation, are described as drivers of mountain diversity (Lobo \& Halffter, 2000; Escobar, Lobo \& Halffter,

43 2006; Schmitt, 2009, Halffter \& Morrone, 2017). Mountain tops can act as refuges for flora and fauna that

44 had expanded during glacial or cooler conditions; as a consequence, their biota exhibits greater

45 differences when compared to that in lower elevations, especially in tropical areas where ecological

46 conditions change dramatically among different altitudes (Körner, 2007).

47 Research exclusively focused on diversity patterns on tropical mountains at elevations higher than 2500

48 MASL is scarce (Mastretta-Yanes et al., 2015). The main focus of diversity patterns in mountains has been 
49 directed to altitudinal gradients, where literature is abundant (Hanski \& Niemelä, 1990; Kessler, 2000;

50 McCain \& Grytnes, 2010; Nogués-Bravo et al., 2008; Rahbek, 1997). Mountain gradients often show

51 higher regional biodiversity due to a high species turnover than areas of the same size in tropical

52 lowlands (Rahbek, 1997). Also, mountains are speciation hotspots with a high degree of endemic species

53 (Halffter, 1987; Marshall \& Liebherr, 2000). In recent times, with earth facing climate change, species of

54 high mountains are thought to be exposed to greater extinction risk, due to a changing ecosystem and

55 upward colonization of species adapted to warmer climates (Cahill et al., 2012).

56 Altitudinal gradients in the tropics present mostly two patterns: 1) decreasing species richness with

57 increasing altitude (e.g. Alvarado, Escobar \& Montero-Muñoz, 2014), or 2) species richness peaks at

58 middle elevations, due to climatic conditions following humidity gradients (e.g. Nunes et al., 2016) or due

59 to geometrical constraints, called mid-domain effect (Colwell \& Hurtt, 1994; Colwell \& Lees, 2000;

60 Colwell, Rahbek \& Gotelli, 2004; Colwell, Rahbek \& Gotelli, 2005). These patterns have in common that

61 diversity is lowest at high elevations.

62 The Mexican Transition Zone (MTZ) is characterized as an area where biotas with Nearctic and

63 Neotropical origins overlap. It extends from the south of the United States to the plains of southern

64 Nicaragua (Halffter \& Morrone, 2017). Since the land connection made by the Panama Bridge, 3.5 million

65 years ago, mountains in the MTZ were primarily dispersion tracks for the northern fauna adapted to cold

66 conditions (which benefited additionally from quaternary glaciations), whereas the lowlands allowed

67 neotropical species to pass through northern areas (Halffter, 1987; Halffter \& Morrone, 2017). As

68 discussed by Halffter (1976), the high level of endemic entomofauna in the MTZ is considered in part a

69 product of speciation following vertical and horizontal colonization, which maintain well-defined affinities

70 with faunas to the south and north (Halffter, 1964; Halffter, 1976; Lobo \& Halffter, 2000).

71 The Trans-Mexican Volcanic Belt (TMVB) is an irregular province oblique to the American Average Trench.

72 It crosses Mexico between $19^{\circ}$ and $21^{\circ}$ northern latitude with a mean elevation of $2300 \mathrm{MASL}$ at its high

73 plateau, where the eight highest volcanoes of Mexico are distributed, which have peak elevations ranging 
74 between 4100 and 5600 MASL (Mooser, 1972; Demant, 1978; Ferrari et al., 1999). The TMVB is one of

75 the largest physiographic provinces in Mexico, formed during the Cenozoic (65 Ma to the present), and

76 one of the best studied mountain system of the MTZ (Arroyo-Cabrales et al., 2008). In general, locally low

77 diversity of TMVB has been described, but with a high species turnover and a high degree of endemic

78 species (Munguía, 2004). Nevertheless, not much is known about diversity patterns above 2500 MASL

79 (Mastretta-Yanes et al., 2015).

80 Dung beetles are one of the best studied insect groups in Mexico and in the tropics in general; compared

81 to many other insect groups their ecology, natural history, biogeography and diversity patterns are well

82 known (Halffter, 1991; Halffter \& Edmonds, 1982; Halffter \& Matthews, 1966; Hanski \& Cambefort, 1991;

83 Scholtz, Davis \& Kryger, 2009). For these reasons, dung beetles have been used widely as a biodiversity

84 indicator group (Halffter \& Favila, 1993; Nichols \& Gardner, 2010). Commonly, the term dung beetle is

85 used for the three subfamilies Scarabaeinae, Aphodiinae, and Geotrupinae, all belonging to the

86 Scarabaeoidea superfamily. Whereas Scarabaeinae are most diverse and abundant in the tropics, the two

87 latter groups are more diverse in northern temperate regions (Hanski \& Cambefort, 1991). In the Mexican

88 Transition Zone, all groups coincide at the same latitudes, but at different richness and abundance levels

89 depending mostly on the elevation (Halffter, 1987; Halffter \& Morrone, 2017). Halffter (1976) proposed

90 and discussed that the entomofauna in the MTZ could not only be separated into Northern or Southern

91 origin, but regarding their dispersal patterns (DP), which were defined as the actual distribution of a

92 group of biota originating in a defined area and coexisting for a long period, thus sharing a common

93 biogeographic history (Halffter \& Morrone, 2017). Besides Neotropical and Nearctic DP, the

94 Paleoamerican DP is abundant, which corresponds to species distributed in the zone long before both

95 Americas were interconnected (Halffter, 1987; Halffter \& Morrone, 2017). Geotrupinae present Nearctic

96 DP, Aphodiinae Nearctic as well as Neotropical DP, while Scarabaeinae show the highest variety, including

97 Neotropical DP, and different subgroups of the Paleoamerican DP (Halffter \& Morrone 2017). In tropical

98 mountain gradients, Scarabaeinae were featured by patterns already described, with peaks at lowlands 
99 or mid-elevations; in contrast, Aphodiinae and Geotrupinae were absent or rare at lowlands or mid-

100 elevations, increasing their diversity at elevations higher than 2000 MASL or sometimes are exclusively

101 limited to these altitudes (Hanski \& Cambefort, 1991).

102 This work represents the first study of diversity patterns of dung beetles carried out at high mountains, at

103 altitudes between 2700 and 3400 MASL. No comparable studies were found in the literature, as high

104 mountains were mostly approached as part of altitudinal gradient studies, where sampling effort at high

105 elevations were comparably low (Davis, Scholtz \& Chown, 1999; Lobo \& Halffter, 2000; Escobar et al.,

106 2007; Herzog et al., 2013).

107 The aims of this research are: first, to study dung beetle diversity patterns at MTZ high mountains

108 extensively in order to collect representative data on species richness and composition, as a lack of

109 sampling intensity in former studies was identified; second, to analyze compositional similarity at

110 different spatial scales within and between MTZ mountains; and finally, to provide information that could

111 indicate the probable origin of diversity patterns, focusing on biogeographical factors (e.g. vertical and

112 horizontal colonization, speciation), as well as ecological variables (e.g. elevation, exposure, forest

113 mosaics). We predict that a) dung beetle alpha and gamma diversity of tropical high mountains in the

114 Mexican transition zone will be higher than previously documented in altitudinal gradient studies; b)

115 compositional similarity within mountains will be relatively high, with the expected small differences

116 between sampling sites explained by altitude, cardinal direction, and forest mosaics; and c)

117 compositional similarity between mountains will be low, because each mountain is largely defined by its

118 own history and dung beetle fauna.

\section{Methods}

\section{Sampling sites}

121 Four mountains were sampled in the Trans Mexican Volcanic Belt: La Malinche (4460 MASL), Cofre de 122 Perote (4200 MASL), Pico de Orizaba (5610 MASL), and Sierra Negra (4580 MASL; mountains are 
123 abbreviated as: MA, CP, PO and SN, respectively; see Fig. 1). The three latter volcanoes separate the

124 Mexican High Plateau from the coastal plains of the Gulf of Mexico (Concha-Dimas et al., 2005). The

125 eastern part of the TMVB is the most recent one, and the peaks studied are modern in their current

126 form. The oldest is the Malinche volcano, followed by Cofre de Perote, Sierra Negra and Pico de Orizaba

127 (Carrasco-Núñez, 2000; Siebert \& Carrasco-Nuñez, 2002; Neyra-Jauregui, 2012).

128 Volcanoes vegetation between 2500 and 3500 MASL is characterized by a high degree of heterogeneity, 129 naturally consisting of a mosaic of pine forest, shrubland, and pastures. The treeline is up to $4020 \mathrm{MASL}$

130 (Körner \& Paulsen, 2004). Pine forest is dominated by species of Pinus and Abies (e.g. P. hartwegii LINDL

131 and A. religiosa (KUNTH) SCHLTDL \& CHAM). They are abundant at all four mountains (Neyra Jauregui,

132 2012). This forest is characterized by a semi-open canopy which allows sunlight to reach the ground,

133 where shrubs and grasses can grow. Vegetation structure is also heterogeneous in terms of tree age,

134 height and basal area; and patches where trees at an early stage of succession are frequent.

135 Due to human influence in the TMVB during the past centuries, high mountain landscapes are modified, 136 and natural vegetation was replaced by crops and pastures for livestock. Milpa (the traditional 137 Mesoamerican non-intensive polyculture system of maize, beans and other plants) is the principal 138 agroecosystem at the region, at higher altitudes non-intensive potato crops, and at lower sites more 139 intensive corn crops are recurrent. Locally, natural pastures are used for cattle and goat grazing. Forest 140 extension differs among volcanoes; MA has the greatest forest area, followed by CP and PO, while SN 141 presents the least extent forest.

\section{Sampling design}

143 At each mountain, four sampling sites were chosen at two different altitudes ( 2700 and 3400 MASL)

144 and on two directions (windward/east and leeward/west). Due to the heterogeneity of the vegetation, no 145 homogeneous sampling sites could be established. Instead, sampling sites reflected vegetation variability 146 of the forest-shrubland-pasture mosaic. 
147 At MA the two upper sampling sites were dominated by forest, whereas the FSP mosaic prevailed in

148 lower sites. At higher sites at CP, a forest-shrubland (FS) mosaic was abundant, where the forest

149 dominated larger parts of it, with pasture present only at the west. The eastern lower sampling site was

150 formed by a well-conserved forest, whereas the western site had a FS mosaic (without dominance of

151 any), with pastures nearby. The FSP mosaics at upper sites in PO were shrubland-pasture dominated in

152 the west, and more forest dominated in the east. The western lower site consisted of an open forest with

153 pastures in the treeless areas. At the eastern lower site the FSP mosaic was dominated by forest,

154 surrounded by milpas. At SN all sites were formed by FSP mosaics.

155 Sampling was accomplished during the rainy seasons (June - August) from 2011 to 2013. Ten pitfall traps

156 baited with human dung were placed at each site, separated at least by 50m (Larsen \& Forsyth 2005), left

157 for 48 hours and repeated once. Traps were placed exclusively in the natural vegetation types (forest,

158 shrubland or pasture), but not in crops or pastures used for cattle grazing. The sampling effort was the

159 same, totaling 240 trap days per mountain. This protocol was followed each year, intercalating months

160 for each mountain (e.g. MA was sampled in June 2011, July 2012 and August 2013, see Table S1). Later,

161 dung beetle composition and abundance of each site were recorded. Direct sampling was done during

162 the three years, collecting inside gopher nests and in livestock excrements, in order to capture species 163 not attracted by baits. Nevertheless, these species and individuals were not used in the analysis, but 164 results are included in the discussion. Field experiments were performed with a permission of the

165 Secretaria del Medio Ambiente y Recursos Naturales, Mexico (FAUD-0018). Species were identified by

166 experts for each of the subfamilies: Marco and Giovanni Dellacasa (Universita di Pisa) determined 167 Aphodiinae, Mario Zunino (Universita di Urbino) and Gonzalo Halffter the Scarabaeinae and Geotrupinae 168 species. All the vouchers were deposited in entomological collections: Dellacasa (Genova, Italy), Morón 169 (Xalapa, Mexico) and Halffter (Xalapa, Mexico) personal collections, as well as a reference collection in 170 the Colección Entomológica IEXA, INECOL (Xalapa, Mexico). 


\section{Analysis}

172 Unweighted diversity partition based on Hill Numbers proposed by Lou Jost (Hill, 1973; Jost, 2006; Jost, 173 2007) was applied using orders $q=0$ and 2 , where the first is equal to species richness, the latter 174 manifests patterns for abundant species, and their unit is the effective number of species. The formula is:

$$
{ }^{q} D=\left(\sum_{i=1}^{S} p_{i}^{q}\right)^{1 /(1-q)}
$$

175 These methods are now widely used and have been described in detail many times (Arroyo-Rodríguez et 176 al., 2013; Jost, 2007; Martínez et al., 2009; Murillo-Pacheco et al., 2016). In the unweighted form, mean 177 relative abundance is used to determine gamma diversity. Beta diversity is the quotient of gamma 178 diversity and mean alpha diversity, and varies between 1 (when species are the same in all sampling 179 units), and the number of sampling units (when all species are different). Because different scales with 180 different numbers of sampling units were compared, compositional similarity ${ }^{9} \mathrm{CS}$ as a direct 181 transformation of beta diversity ${ }^{9} \beta$ was used:

${ }^{\mathrm{q}} \mathrm{CS}=\left(1 /{ }^{\mathrm{q}} \beta-1 / \mathrm{N}\right) /(1-1 / \mathrm{N})$

183 This converts beta diversity into values between 0 (no similarity) and 1 (complete similarity). More

184 generally speaking, ${ }^{9} \mathrm{CS}$-values below 0.33 were considered as low and values above 0.66 as high 185 similarity. ${ }^{\mathrm{C}} \mathrm{CS}$ for $\mathrm{q}=0$ and $\mathrm{N}=2$ equals the Jaccard index, and for $\mathrm{q}=2$ the Morisita-Horn index.

186 Entropart package in the R-program for diversity partition was used (Marcon, Herault \& Marcon, 2014; R-

187 Development-Core-Team 2009). Chao 1 richness estimator, as well as sampling coverage, was calculated 188 in order to address sampling completeness for each mountain (Colwell, 2010; Chao \& Jost, 2012).

189 Homogeneity of multivariate dispersion using Jaccard and Morisita-Horn dissimilarity indices was carried 190 out (Anderson, 2001) applying permutation test based on 999 repetitions and Tukey's Honest Significant 191 Difference method with the vegan package in R (Oksanen et al., 2007, R-Development-Core-Team 2009). 
192 Sampling units were the 16 sites, grouped by mountains or by three FSP mosaic classes (see

193 Supplementary Material).

194 Species were classified regarding their dispersal patterns as: Neotropical (NT), Mexican High Plateau 195 (Neotropical origin), Meso-American Montane (MM, species evolved in Mesoamerican mountains but of 196 both northern and southern origin), Nearctic (of recent northern origin), and Paleo-American (which

197 Halffter divided into the subpatterns Mountain Paleo-American, Paleo-American High Plateau and 198 Tropical Paleo-American; Halffter, 1964; Halffter, 1976; Halffter, 1978).

\section{Results}

2003430 individuals of 29 species at the four mountains were collected during the three sampling seasons

201 (see Table 1). The most diverse subfamily was Aphodiinae with 16 species in 10 genera, followed by 202 Scarabaeinae (eight species in three genera) and Geotrupinae (five species in three genera). The most 203 abundant subfamily was Scarabaeinae with $60 \%$ of all individuals, followed by Aphodiinae and 204 Geotrupinae (25\% and 15\%, respectively). These percentages are nearly the same across altitudes and 205 sites. Regarding different altitudes, 25 species were collected at lower altitudes (with ten unique species) 206 versus 19 species at superior altitudes (with four unique species). Of the 29 species, five were captured at 207 all volcanoes; seven species were restricted to two and 13 were unique to one of the four volcanoes. 208 Sampling completeness was high, values of Chao 1 estimators were $92 \%$ for the pooled mountains, and $20996 \%, 81 \%, 89 \%, 78 \%$ for each of the mountains (MA, CP, PO, and SN respectively), and sampling coverage 210 varied between 98.7 and $99.9 \%$ (see Table 1 ).

211 Variability was the most consistent pattern at all scales and measures (dung beetle diversity, abundance, 212 and compositional similarity, see Fig. 2 and 3). Among and within all mountains, there were a high 213 variation of diversity and abundance values (Fig. 2): richness varied between 2 and 15 species and from 2141.1 to 4.7 effective species for order $q=2$. The abundance ranged from 9 (SN upper leeward site) to 585 215 individuals (PO lower western site). On the same mountain, measures could vary between sites by three- 
216 fold $\left({ }^{\circ} \mathrm{D}\right.$ at $\mathrm{PO},{ }^{2} \mathrm{D}$ at $\left.\mathrm{CP}\right)$ to as much as 24 -fold (abundance at MA). At each mountain, the forest-

217 dominated sites did not have higher or lower diversity, abundance or CS values when compared to the

218 sites with a FSP mosaic, and were similarly variable (Fig. 2 and 3, Fig. S1).

219 Comparing mountains, PO had the highest diversity and abundance. CP presented the second highest

220 species richness and abundance, and the lowest compositional similarity. SN had by far the lowest alpha

221 and gamma diversity (less than $50 \%$ of adjacent PO), as well as abundances ( $20 \%$ compared to PO, see

222 Fig. 2), whereas CS varied similarly as in MA and PO. At CP, the relatively high gamma diversity was

223 product of the high beta diversity. Compositional similarity demonstrated differences among and within

224 mountains depending on the order q. CP had the lowest CS for both q=0 and 2. Sites at Sierra Negra

225 shared only a few species, but the abundant species were most similar, so ${ }^{\circ} \mathrm{CS}$ was nearly as low as at CP,

226 but ${ }^{2} \mathrm{CS}$-value was the highest of all mountains. MA had the highest CS values for order $\mathrm{q}=0$ (although

227 they were not high), and second highest for order=2.

228 Compositional similarity between pairs of mountains did not increase with distance (Fig. 4). Species

229 similarity was relatively low among mountains $(0.3-0.38)$, with the exception of the ${ }^{\circ} \mathrm{CS}$ between $\mathrm{CP}$ and $230 \mathrm{PO}(0.5)$.

231 The Scarabaeinae Onthophagus chevrolati chevrolati Harold dominated all mountains, with $50 \%$ of all 232 collected individuals, and its distribution pattern was principally responsible for the higher ${ }^{2} \mathrm{CS}$-values

233 between all mountains (see Fig. 4). ${ }^{2} \mathrm{CS}$ was the highest between CP and PO with 0.84 , meaning that

234 similarity was greater between these two mountains at a $53 \mathrm{~km}$ distance than between PO and SN at a

235 distance of $7 \mathrm{~km}$. The great dominance of $O$. ch. chevrolati hid the high variability of the other species, as

236 shown in the Table in Fig. 4. When omitting O. ch. chevrolati from the analysis, ${ }^{2} \mathrm{CS}$ turned into low values,

237 and in general, it decreased as distance increased.

238 The permutation test for beta diversity did not reveal significant differences in variability among 239 mountains, aiming that, as already described as the general diversity pattern for our study, variability was 240 similarly high at all mountains (Fig. S1). 
241 Temporal variation was also high; each year approximately $60 \%$ of overall richness was collected (Table

242 S1). The most abundant species, O. ch. chevrolati was present at each mountain every year. In contrast,

243 eight species were present only at one mountain one year. Most species also varied highly regarding

244 abundance between years, inclusive at the same mountain. Each year, every mountain displayed different

245 richness and compositional similarity (see Table S1\&2).

246 Dispersion patterns exhibited differences among mountains; for instance, species representing the

247 Nearctic Pattern were absent in MA but abundant in CP and present in PO. Pico de Orizaba was the only

248 mountain with one Mesoamerican Montane Pattern species. Paleoamerican Mountain pattern

249 dominated both at species and individual level, at all mountains. SN was almost entirely dominated by

250 individuals of PM-species (Fig. S2).

251 Regarding taxonomic differences, MA had by far the highest percentage of Scarabaeinae individuals and

252 species. On the other three volcanoes, Aphodiinae presented the highest species richness, while

253 Scarabaeinae had the highest abundance. Geotrupinae showed the highest variation in abundance, being

254 most abundant on PO and least abundant on the adjacent SN (Fig. S2).

\section{Discussion}

256 As predicted, this study provides evidence that high mountains can hold a diverse dung beetle

257 community. Unexpected and contrary to our predictions, we found high variability in diversity patterns at

258 different spatial scales, both within and between mountains. No previous studies on dung beetles in

259 Mexico have reported species richness numbers for these elevations: Martin-Piera \& Lobo (1993)

260 collected five species above 2500 MASL; Lobo \& Halffter (2000) collected seven species; Escobar, Halffter

261 \& Arellano (2007) only two; Halffter et al. (2008) eight species; and Alvarado, Escobar \& Montero-Muñoz

262 (2014) four species (Halffter et al., 2008 did not report Aphodiinae and Escobar, Halffter \& Arellano, 2007

263 only Scarabaeinae). Of these, only Lobo \& Halffter (2000) collected three species at 3300 MASL, whereas

26419 species were found in this study. 
265 More than ten percent of species collected were new to science (Arriaga-Jiménez et al. 2016; Dellacasa,

266 Dellacasa \& Gordon, 2014). The three new species belong to the Paleoamerican Mountain DP, which

267 Halffter and Morrone (2017) described as corresponding to lineages that have undergone vicariant

268 speciation. The discovery of Onthophagus bolivari, which probably evolved in the mountain complex of

269 La Malinche and El Pinal (Arriaga-Jiménez et al., 2016) highlights the importance of the O. chevrolati

270 species group, whose distribution reflects the MTZ and which now comprises more than 40 species and

271 subspecies (Zunino \& Halffter, 1988). In addition, some species at high mountains developed particular

272 feeding behaviors, living exclusively in gopher nests (Rodentia: Cratogeomys), feeding on excrements

273 stored in latrines (Zunino \& Halffter, 1988; Zunino \& Halffter, 2007). Four dung beetle species

274 (Onthophagus hippopotamus, Geomyphilus pierai, G. barrerai, and Neotrichonotulus perotensis, see

275 Table S2) were collected only in the gopher nests, as they were not attracted to bait (thus explaining why

276 they could not be included in the diversity analysis), but they also support the conclusion that high

277 mountains are a center of speciation associated with a unique, highly-adapted dung fauna.

278 Dispersion processes may be the main driver of dung beetle richness and composition in mountains, as

279 only some species are restricted to one or few mountain chains. Lobo \& Halffter (2000) discussed how

280 mountains of the TMVB illustrate horizontal colonization - an observation that is indeed supported by

281 the dispersal patterns (DP) of most species collected in this study. As observed by Caballero et al. (2011),

282 temperature and vegetation equivalents in the last glacial maximum were distributed $1000 \mathrm{~m}$ below the

283 current altitudes. As a consequence, these conditions were not limited to mountain tops as is the case

284 today, but instead connected over large areas. As there have been more glaciation periods in the MTZ,

285 these habitat replacements with repeated separations and a mix of faunas might have been common

286 (Zunino \& Halffter, 1988). Halffter and Morrone (2017) stated that in the MTZ vertical colonization

287 occurred rarely in relation to horizontal colonization and in comparison to other tropical regions.

288 Nevertheless, several species with Neotropical DP (Lobo \& Halffter, 2000 only reported one species) show 
289 that vertical colonization events also contributed to species richness and composition in the TMBV (Lobo

$290 \&$ Halffter, 2000).

291 Whereas speciation and dispersal patterns may explain dung beetle richness and composition of the four

292 volcanoes studied, they do not explain the high variability of diversity and compositional similarity

293 patterns found at different spatial scales.

294 Volcanoes in the TMVB can be considered as dynamic, ecologically instable systems with a comparably

295 strong disturbance regime at different time scales. Volcanism, earthquakes and glaciations cause long-

296 term temporal effects of habitat destruction and perturbation, leading to local extinctions and population

297 splitting, followed by speciation, and recolonization (Zunino \& Halffter, 1988; Siebe et al., 1996; Castro-

298 Govea \& Siebe, 2007; Battisti, Poeta \& Fanelli, 2016).

299 Severe climate, diverse soil conditions, and the resulting forest-shrubland-pasture mosaic form

300 heterogeneous conditions of permanent environmental instability. Because dung beetles are mainly

301 linked to herbivorous mammals, they may be especially vulnerable to environmental instability (Nichols

302 et al., 2009). It has often been reported that diversity patterns produced by instability are high regional

303 diversity, due to lower local (alpha) diversity but higher beta diversity (Halffter et al., 2007; Martínez et

304 al., 2015; Battisti, Poeta \& Fanelli, 2016). While our study provides some support for such patterns (e.g.

305 for Cofre de Perote), instability seems nevertheless to lead to highly variable patterns: high and low

306 abundance, diversity and compositional similarity, without any apparent linkage to measured ecological

307 variables. Also, the dominance of 0 . ch. chevrolati may hide a clearer pattern of the expected low

308 similarity; it is not common that one species dominates a dung beetle community to such a degree that

309 similarity patterns change totally when it is excluded from analyses. O. ch. chevrolati, also present in

310 other studies of the region (Lobo \& Halffter, 2000; Escobar, Halffter \& Arellano, 2007), is abundant in all

311 mountains of the TMVB in forest and pastures, and it is the species with the highest known elevation

312 record in Mexico at 3800 MASL (Zunino \& Halffter, 1988). Nevertheless, there is little information about

313 its natural history or physiological adaptations to high mountain climates and habitats. This species 
314 belongs to a recent lineage in an ongoing phase of dispersion (Zunino \& Halffter, 1988). As shown in the

315 results, when excluding 0 . ch. chevrolati from CS analysis for order $\mathrm{q}=2$ (regarding abundant species), the

316 community presented a large degree of heterogeneity and dynamism. Even the remaining most frequent

317 species had dissimilar abundances on each mountain, indicating that dynamics are independent and

318 different on each volcano. Severe climate and environment could cause high population fluctuations,

319 where low densities of individuals result in a lower species detectability (MacKenzie et al., 2003).

320 Alternatively, we found some species to be active only in a small window of time due to their biological

321 cycles (e.g. Cephalocyclus). Our temporal data indicate high fluctuations from year to year and between

322 volcanoes for these species, although they could not be linked directly to climate data.

323 The observed patterns of diversity and heterogeneity could be typical for the entire MTZ, with lower

324 values of diversity and heterogeneity near its northern and southern limits, and more endemisms in the

325 southern part of the zone (Zunino \& Halffter, 1988). As elevation increases, the species turnover is

326 predicted to be higher: Scarabaeinae richness (a temperate and tropical group), will be replaced by

327 species of Aphodiinae (a heterogeneous group with different origins) and Geotrupinae (a northern group

328 of colder climates). Because of its origins, Geotrupinae will lose importance southwards, whereas

329 Aphodiinae and Scarabaeinae will present still high richness and abundance. By contrast, in the

330 Neotropical region, Geotrupinae cannot compete with Scarabaeinae (Hanski \& Cambefort, 1991), and are

331 absent in high mountains. Scarabaeinae richness decreases at higher mountain altitudes, sharing only

332 some species with the MTZ (Escobar et al. 2007; Halffter \& Morrone 2017; Howden 1964). Distribution of

333 Aphodiinae species are not well documented for high mountains, so it is not clear if they show similar

334 richness patterns as in the TMBV, or if they are mostly absent. The fact that dung beetles are frequently

335 studied in altitudinal gradients may erroneously lead to the assumption that their high mountain

336 diversity patterns are well understood. This work reveals the need to conduct more extensive studies at

337 high elevations in tropical montane systems to understand some of these as-yet unresolved issues

338 surrounding dung beetle diversity, biogeography and evolution. 
339 Present conservation strategies do not protect all the high mountain fauna since reserves are situated

340 mostly at higher altitudes. New proposals such as archipelago reserves (Halffter, 2005; Halffter, 2007)

341 may be an adequate tool, given mountain tops have limited areas with similar ecological conditions and

342 similar threats (land use intensification, climate change). These systems would also benefit from

343 coordinated monitoring and conservation programs.

344 Future studies should prioritize representative sampling of other mountains in the MTZ. Volcanic

345 mountains, dominant from Mexico to Central America, should be compared to mountains of different

346 origin. For instance, some regions in the adjacent Mexican states of Oaxaca or Chiapas had different

347 disturbance patterns over a large temporal scale, which could lead to different diversity patterns. South

348 America also has a heterogeneous mix of high mountains with and without volcanic activity, so there may

349 be differences between them and Mexico. More importantly, though, the biogeographical history and

350 dispersal patterns in the Andes differ strongly from those of the MTZ. Less is known about Asian tropical

351 high mountains, despite the fact that all three dung beetle groups are present there. Filling in some of

352 these research gaps will allow comparison of these mountain regions and will improve our understanding

353 of species diversity and turnover in high mountain ecosystems. Despite the research needs that remain,

354 our study nevertheless makes progress by providing evidence of how tropical high mountains can

355 improve our understanding of the drivers of diversity patterns, and how biogeographic history and

356 ecological factors mold them. This knowledge is important to improve the conservation of these unique

357 and restricted ecosystems.

\section{Acknowledgements}

359 We thank Fernando Escobar (Instituto de Ecología, A.C.) for his valuable aid for field work and curatorial

360 work for the beetles collected. Three anonymous reviewers provided valuable comments which helped

361 us to improve the manuscript. We are grateful to Maria del Sagrario Velasco García and Mauricio

362 Rodriguez Herrera who revised the English version of this manuscript. 
364

365

366

367

368

369

370

371

372

373

374

375

376

377

378

379

380

381

382

383

384

385

386

387

388

389

390

391

392

393

394

395

396

397

398

399

400

401

402

403

404

405

406

407

408

409
Alvarado F, Escobar F, Montero-Muñoz J. 2014. Diversity and biogeographical makeup of the dung beetle communities inhabiting two mountains in the Mexican Transition Zone. Organisms Diversity \& Evolution 14:105-114.

Anderson MJ. 2001. A new method for non parametric multivariate analysis of variance. Austral Ecology 26:32-46.

Arriaga-Jiménez A, Moctezuma V, Rossini M, Zunino M, Halffter G. 2016. A new species of Onthophagus (Scarabaeoidea: Scarabaeinae) from the Mexican Transition Zone, with remarks on its relationships and distribution. Zootaxa 4072:135-143.

Arroyo-Cabrales J, Carreño A, Lozano-García S, Montellano-Ballesteros M, Cevallos-Ferriz S, Corona E. 2008. La diversidad en el pasado. Capital natural de México 1:227-262.

Arroyo-Rodríguez V, Rös M, Escobar F, Melo FP, Santos BA, Tabarelli M, Chazdon R. 2013. Plant $\beta$-diversity in fragmented rain forests: testing floristic homogenization and differentiation hypotheses. Journal of Ecology 101:1449-1458.

Battisti C, Poeta G, Fanelli G. 2016. An Introduction to Disturbance Ecology: A Road Map for Wildlife Management and Conservation. 177pp. Springer.

Caballero, M., Lozano-García, S., Vázquez-Selem, L. \& Ortega, B. (2011) Evidencias de cambio climático y ambiental en registros glaciales y en cuencas lacustres del centro de México durante el último máximo glacial. Boletín de la Sociedad Geológica Mexicana, 62, 359-377.

Cahill AE, Aiello-Lammens ME, Fisher-Reid MC, Hua X, Karanewsky CJ, Yeong Ryu H, Sbeglia GC, Spagnolo F, Waldron JB, Warsi O, Wiens JJ. 2012. How does climate change cause extinction? Proceedings of the Royal Society B: Biological Sciences. $10.1098 /$ rspb.2012.1890

Carrasco-Núñez G. 2000. Structure and proximal stratigraphy of Citlaltépetl volcano (Pico de Orizaba), México. Pp. 247262. In: Delgado Granados H., Aguirre Díaz G., J.M. Stock (eds.). Cenozoic volcanism ad tectonics of Mexico: Boulder, Colorado. Geological Society of America, special paper.

Castro-Govea R, Siebe C. 2007. Late Pleistocene-Holocene stratigraphy and radiocarbon dating of La Malinche volcano, Central Mexico. Journal of Volcanology and Geothermal Research 162:20-42.

Colwell R. 2010. EstimateS: Statistical estimation of species richness and shared species from samples. Version 8.2.

Colwell RK, Hurtt GC. 1994. Nonbiological gradients in species richness and a spurious Rapoport effect. American Naturalist:570-595.

Colwell RK, Lees DC. 2000. The mid-domain effect: geometric constraints on the geography of species richness. Trends in Ecology \& Evolution 15:70-76.

Colwell RK, Rahbek C, Gotelli NJ. 2004. The Mid-Domain Effect and Species Richness Patterns: What Have We Learned So Far? The American Naturalist 163:E1-E23.

Colwell RK, Rahbek C, Gotelli NJ. 2005. The Mid-Domain Effect: There's a baby in the bathwater. The American Naturalist 166:E149-E154.

Concha-Dimas A., Cerca M., Rodríguez S.R., Watters R.J. 2005. Geomorphological evidence of the incluence of pre-volcanic basement structure on emplacement and deformation of volcanic edifices at the Cofre de Perote-Pico de Orizaba chain and implications for avalanche generation. Geomorphology, 72: 19-39.

Chao A, Jost L. 2012. Coverage-based rarefaction and extrapolation: standardizing samples by completeness rather than size. Ecology. 
410

411

412

413

414

415

416

417

418

419

420

421

422

423

424

425

426

427

428

429

430

431

432

433

434

435

436

437

438

439

440

441

442

443

444

445

446

447

448

449

450

451

452

453

454

455

456

457

Davis ALV, Scholtz CH, Chown SL. 1999. Species turnover, community boundaries and biogeographical composition of dung beetle assemblages across an altitudinal gradient in South Africa. Journal of Biogeography 26:1039-1055. 10.1046/j.1365-2699.1999.00335.x

Dellacasa M, Dellacasa G, Gordon RD. 2014. Systematic revision of the genus Trichonotuloides Balthasar, 1945 with description of two new Mexican species (Coleoptera: Scarabaeidae: Aphodiinae).

Demant A. 1978. Características del eje neovolcánico transmexicano y sus problemas de interpretación. Universidad Nacional Autónoma de México: Instituto de Geología Revista, 2: $172-187$.

Escobar F, Halffter G, Arellano L. 2007. From forest to pasture: An evaluation of the influence of environment and biogeography on the structure of dung beetle (Scarabaeinae) assemblages along three altitudinal gradients in the Neotropical region. Ecography 30:193-208.

Escobar F, Lobo J, Halffter G. 2006. Assessing the origin of Neotropical mountain dung beetle assemblages (Scarabaeidae: Scarabaeinae): the comparative influence of vertical and horizontal colonization. Journal of Biogeography 33:1793-1803.

Ferrari L., López-Martínez M., Aguirre-Díaz G., Carrasco-Núñez G. 1999. Space-time patterns of Cenozoic arc volcanism in Central Mexico: from the Sierra Madre Occidental to the Mexican Volcanic Belt. Geology, 27 (4): 303-306.

Halffter G. 1964 La entomofauna americana: ideas acerca de su origen y distribución. Folia Entomológica Mexicana, 6: 1108.

Halffter G. 1976. Distribución de los insectos en la Zona de Transición Mexicana. Relaciones con la entomofauna americana. Folia Entomológica Mexicana, 35: 1-64.

Halffter G. 1978. Un nuevo patrón de dispersión en la Zona de Transición Mexicana: el mesoamericano de montaña. Folia Entomológica Mexicana, 39-40: 219-222.

Halffter G. 1987. Biogeography of the montane entomofauna of Mexico and Central America. Annual Review of Entomology 32:95-114.

Halffter G. 1991. Historical and ecological factors determining the geographical distribution of beetles (Coleoptera: Scarabaeidae: Scarabaeinae). Folia Entomológica Mexicana 82:195238.

Halffter G. 2005. Towards a culture of biodiversity conservation. Acta Zoológica Mexicana 21:133-153.

Halffter G. 2007. Reservas archipiélago: un nuevo tipo de área protegida. In: Halffter G, Guevara $\mathrm{S}$, Melic A, eds. Hacia una Cultura de Conservación de la Biodiversidad Biológica. Zaragoza, España: Monografias Tercer Milenio, 281-286.

Halffter G, Edmonds W. 1982. The nesting behavior of dung beetles (Scarabaeinae): An ecological and evolutive approach. Instituto de Ecologia (Mexico, DF.). p 242.

Halffter G, Favila M. 1993. The Scarabaeinae (Insecta: Coleoptera), an animal group for analysing, inventoring and monitoring biodiversity in tropical rainforest and modified landscapes. Biology International 27:15-21.

Halffter G, Matthews EG. 1966. The natural history of dung beetles of the subfamily Scarabaeinae. Mexico D.F.: Sociedad Mexicana de Entomologia.

Halffter G, Morrone JJ. 2017. An analytical review of Halffter's Mexican transition zone, and its relevance for evolutionary biogeography, ecology and biogeographical regionalization. Zootaxa 4226:1-46.

Halffter G, Pineda E, Arellano L, Escobar F. 2007. Instability of Copronecrophagous Beetle Assemblages (Coleoptera: Scarabaeinae) in a Mountainous Tropical Landscape of Mexico. Environmental Entomology 36:1397-1407. 
458

459

460

461

462

463

464

465

466

467

468

469

470

471

472

473

474

475

476

477

478

479

480

481

482

483

484

485

486

487

488

489

490

491

492

493

494

495

496

497

498

499

500

501

502

503

504

505

506

Halffter G, Verdú JR, Márquez J, Moreno CE. 2008. Biogeographical analysis of Scarabaeinae and Geotrupinae along a transect in central Mexico (Coleoptera, Scarabaeoidea). Fragmenta entomologica 40:273-322.

Hanski I, Cambefort Y. 1991. Dung beetle ecology. Princeton, New Jersey: Princeton University Press.

Hanski I, Niemelä J. 1990. Elevational distributions of dung and carrion beetles in Northern Sulawesi. Insects and the rain forests of South East Asia (Wallacea):145-152.

Herzog, S. K., A. C. Hamel-Leigue, T. H. Larsen, D. J. Mann, R. W. Soria-Auza, B. D. Gill, W. D. Edmonds, S. Spector. 2013. Elevational Distribution and Conservation Biogeography of Phanaeine Dung Beetles (Coleoptera: Scarabaeinae) in Bolivia. Plos One 8:e64963.

Hill M. 1973. Diversity and evenness: a unifying notation and its consequences. Ecology 54:427432.

Howden HF. 1964. The Geotrupinae of North and Central America. Memoirs of the Entomological Society of Canada 96:5-91.

Jost L. 2006. Entropy and diversity. Oikos 113:363-375.

Jost L. 2007. Partitioning diversity into independent alpha and beta components. Ecology 88:2427-2439.

Kessler M. 2000. Elevational gradients in species richness and endemism of selected plant groups in the central Bolivian Andes. Plant Ecology 149:181-193. 10.1023/a:1026500710274

Körner C. 2000. Why are there global gradients in species richness? Mountains might hold the answer. Trends in Ecology and Evolution 15:513-514.

Körner, C. 2007. The use of 'altitude' in ecological research. Trends in Ecology \& Evolution 22:569-574.

Körner, C. J. Paulsen. 2004. A world-wide study of high altitude treeline temperatures. Journal of Biogeography 31:713-732.

Larsen, T. A. Forsyth. 2005. Trap spacing and transect design for dung beetle biodiversity studies. Biotropica 37:322-325.

Lobo J, Halffter G. 2000. Biogeographical and ecological factors affecting the altitudinal variation of mountainous communities of coprophagous beetles (Coleoptera: Scarabaeoidea): a comparative study. Annals of the Entomological Society of America 93:115-126.

MacKenzie DI, Nichols JD, Hines JE, Knutson MG, Franklin AB. 2003. Estimating Site Occupancy, Colonization, and Local Extinction When a Species Is Detected Imperfectly. Ecology 84:2200-2207.

Marcon E, Herault B, Marcon ME. 2014. Entropart: an R Package to Measure and Partition Diversity.

Marshall CJ, Liebherr JK. 2000. Cladistic biogeography of the Mexican transition zone. Journal of Biogeography 27:203-216. 10.1046/j.1365-2699.2000.00388.x

Martínez E, Rös M, Bonilla MA, Dirzo R. 2015. Habitat Heterogeneity Affects Plant and Arthropod Species Diversity and Turnover in Traditional Cornfields. Plos One 10:e0128950. 10.1371/journal.pone.0128950

Martínez NJ, García H, Pulido LA, Ospino D, Narváez J. 2009. Escarabajos coprófagos (Coleoptera: Scarabaeinae) de la vertiente noroccidental, Sierra Nevada de Santa Marta, Colombia. Neotropical Entomology 38:708-715.

Martín-Piera, F. J. M. Lobo. 1993. Altitudinal distribution patterns of copro-necrophage Scarabaeoidea (Coleoptera) in Veracruz, Mexico. The Coleopterists' Bulletin:321-334.

Mastretta-Yanes A, Moreno-Letelier A, Piñero D, Jorgensen TH, and Emerson BC. 2015. Biodiversity in the Mexican highlands and the interaction of geology, geography and climate within the Trans-Mexican Volcanic Belt. Journal of Biogeography 42:1586-1600. 
507

508

509

510

511

512

513

514

515

516

517

518

519

520

521

522

523

524

525

526

527

528

529

530

531

532

533

534

535

536

537

538

539

540

541

542

543

544

545

546

547 Zunino M., Halffter G. 2007. An analysis of the relationships between Onthophagus beetles 548

McCain, Christy M; Grytnes, John-Arvid (September 2010) Elevational Gradients in Species Richness. In: Encyclopedia of Life Sciences (ELS). John Wiley \& Sons, Ltd: Chichester. DOI: 10.1002/9780470015902.a0022548

Mooser F. 1972. The Mexican Volcanic Belt: Structure and tectonics. Geofisica Internacional, 12(2): 55-70.

Munguía M. 2004. Representación mastofaunística en áreas naturales protegidas y regiones terrestres prioritarias en el Eje Neovolcánico: Un modelo de conservación. Master Thesis. UNAM.

Murillo-Pacheco JI, Rös M, Escobar F, Castro-Lima F, Verdú JR, López-Iborra GM. 2016. Effect of wetland management: are lentic wetlands refuges of plant-species diversity in the Andean-Orinoco Piedmont of Colombia? PeerJ 4:e2267.

Neyra Jauregui JA. 2012. Guía de las altas montañas de Mexico y una de Guatemala. CONABIO, Ciudad de Mexico. 415pp.

Nichols E, Gardner T. 2010. Dung beetles as a focal taxon in applied biodiversity research.

Nichols E, Gardner T, Peres C, Spector S. 2009. Co-declining mammals and dung beetles: an impending ecological cascade. Oikos 118:481-487.

Nogués-Bravo D, Araújo M, Romdal T, Rahbek C. 2008. Scale effects and human impact on the elevational species richness gradients. Nature 453:216-219.

Nunes CA, Braga RF, Figueira JEC, Neves FdS, Fernandes GW. 2016. Dung Beetles along a Tropical Altitudinal Gradient: Environmental Filtering on Taxonomic and Functional Diversity. Plos One 11:e0157442. 10.1371/journal.pone.0157442

Oksanen J, Kindt R, Legendre P, O'Hara B, Stevens MHH, Oksanen MJ, Suggests M. 2007. The vegan package. Community ecology package 10:631-637.

R-Development-Core-Team. 2009. R: A language and environment for statistical computing. R Foundation for Statistical Computing, Vienna, Austria. ISBN 3-900051-07-0. http://www.Rproject.org.

Rahbek C. 1997. The Relationship among Area, Elevation, and Regional Species Richness in Neotropical Birds. The American Naturalist 149:875-902.

Schmitt T. 2009. Biogeographical and evolutionary importance of the European high mountain systems. Frontiers in Zoology 6:9.

Scholtz CH, Davis ALV, Kryger U. 2009. Evolutionary Biology and Conservation of Dung Beetles. Sofia: Pensoft Publisher.

Siebe C, Abrams M, Macías JL, Obenholzner J. 1996. Repeated volcanic disasters in Prehispanic time at Popocatepetl, central Mexico: Past key to the future? Geology 24:399-402.

Siebert L., Carrasco-Núñez G. 2002. Late-Pleistocene to pre-Columbian behind-the-arc mafic volcanism in the eastern Mexican Volcanic Belt; implications for future hazards. Journal of Volcanology and Geothermal Research, 115: 179-205.

Zunino M., Halffter G. 1988. Análisis taxonómico, ecológico y biogeográfico de un grupo americano de Onthophagus (Coleoptera: Scarabaeidae). Monografía IX: 1-211. Museo Regionale di Science Naturali, Turín. 


\section{Table $\mathbf{1}$ (on next page)}

Species sampled at each volcano

Species sampled via pit fall traps, indicating relative abundance percentage for species at each volcano. Values for 4 Volcanos are mean \%. SF=Subfamily; DP= Dispersion Pattern $(\mathrm{HP}=$ High Plateau, $\mathrm{MM}=$ Mesoamerican Montane, $\mathrm{NA}=$ Nearctic, $\mathrm{PM}=$ Paleoamerican, $\mathrm{NT}=$ Neotropical) * DP unknown but assumed according to the genera. Volcanos: MA- Malinche, CP-Cofre de Perote, PO-Pico de Orizaba, SN- Sierra Negra. 


\begin{tabular}{|c|c|c|c|c|c|c|c|}
\hline SPECIES & SF & DP & MA & CP & PO & SN & 4 Volcanos \\
\hline Agrilinellus azteca & A & PM & 0.2 & 8.8 & 8.3 & 5.4 & 5.71 \\
\hline Agrilinellus ornatus & A & $\mathrm{PM}^{*}$ & 2.7 & 0.5 & 4.0 & 17.9 & 6.27 \\
\hline Blackburneus charmionus & A & $\mathrm{NT}^{*}$ & & & 0.1 & & 0.02 \\
\hline Blackburneus guatemalensis & A & $\mathrm{NT}^{*}$ & 0.1 & & 2.8 & & 0.73 \\
\hline Blackburneus saylorea & A & $\mathrm{NT}^{*}$ & & & 0.2 & & 0.04 \\
\hline Cephalocyclus hogei & A & NA & & 24.0 & 3.1 & 0.4 & 6.86 \\
\hline Gonaphodiellus bimaculosus & A & NT & & & 1.3 & & 0.33 \\
\hline Gonaphodiellus ophisthius & A & NT & 1.6 & 0.2 & 8.4 & & 2.54 \\
\hline Labarrus pseudolividus & A & NT & & & & 0.4 & 0.10 \\
\hline Neotrichonotulus inurbanus & A & NA & & 0.1 & & & 0.02 \\
\hline Oscarinus indutilis & A & NA & & 0.1 & 0.1 & & 0.04 \\
\hline Oxyomus setosopunctatus & A & NA & & & 1.3 & & 0.33 \\
\hline Planolinellus vittatus & A & NA & & 0.1 & 0.4 & & 0.12 \\
\hline Trichonotuloides alfonsinae & A & $\mathrm{PM}^{*}$ & & & 0.5 & 0.8 & 0.33 \\
\hline Trichonotuloides feryi & A & $\mathrm{PM}^{*}$ & & 0.1 & & & 0.02 \\
\hline Trichonotuloides glyptus & A & PM & & 1.0 & & & 0.26 \\
\hline Ceratotrupes bolivari & G & PM & 3.6 & 0.8 & 0.1 & 0.4 & 1.23 \\
\hline Halffterius rufoclavatus & G & PM & & 2.1 & 0.3 & & 0.60 \\
\hline Onthotrupes herbeus & G & PM & 2.3 & 1.0 & 24.3 & 0.8 & 7.09 \\
\hline Onthotrupes nebularum & G & PM & 0.6 & 0.2 & 8.8 & & 2.38 \\
\hline Onthotrupes sallei & G & $\mathrm{PM}^{*}$ & & 0.4 & & & 0.11 \\
\hline Copris armatus & $S$ & PM & 11.9 & & & 1.7 & 3.39 \\
\hline Onthophagus aureofuscus & $S$ & PM & & 9.9 & 1.1 & & 2.74 \\
\hline Onthophagus bolivari & S & $\mathrm{PM}^{*}$ & 20.9 & & & & 5.22 \\
\hline Onthophagus ch. chevrolati & S & PM & 38.8 & 50.2 & 34.8 & 72.1 & 49.00 \\
\hline Onthophagus lecontei & S & $\mathrm{HP}$ & 15.4 & 0.6 & & & 4.00 \\
\hline Onthophagus mexicanus & S & HP & 1.3 & & & & 0.33 \\
\hline Phanaeus qu. quadridens & S & HP & 0.5 & & & & 0.12 \\
\hline Phanaeus a. amethystinus & $\mathrm{s}$ & $\mathrm{MM}$ & & & 0.2 & & 0.04 \\
\hline Individuals & & & 824 & 1155 & 1211 & 240 & 3430 \\
\hline Richness & & & 13 & 17 & 19 & 9 & 29 \\
\hline Chao1/Coverage (\%) & & & 96/99.9 & $81 / 99.7$ & $89 / 99.7$ & 78/98.7 & 92/99.9 \\
\hline
\end{tabular}




\section{Figure 1}

Map of the study area

Map of the study sites in the Trans Mexican Volcanic Belt (indicated by the rectangle), with the four sampled volcanos (indicated by triangles). MA- La Malinche, CP - Cofre de Perote, PO - Pico de Orizaba, SN - Sierra Negra. The map is based on the Digital Elevation Model for Mexico, provided by INEGI (downloadable at www.inegi.org.mx).

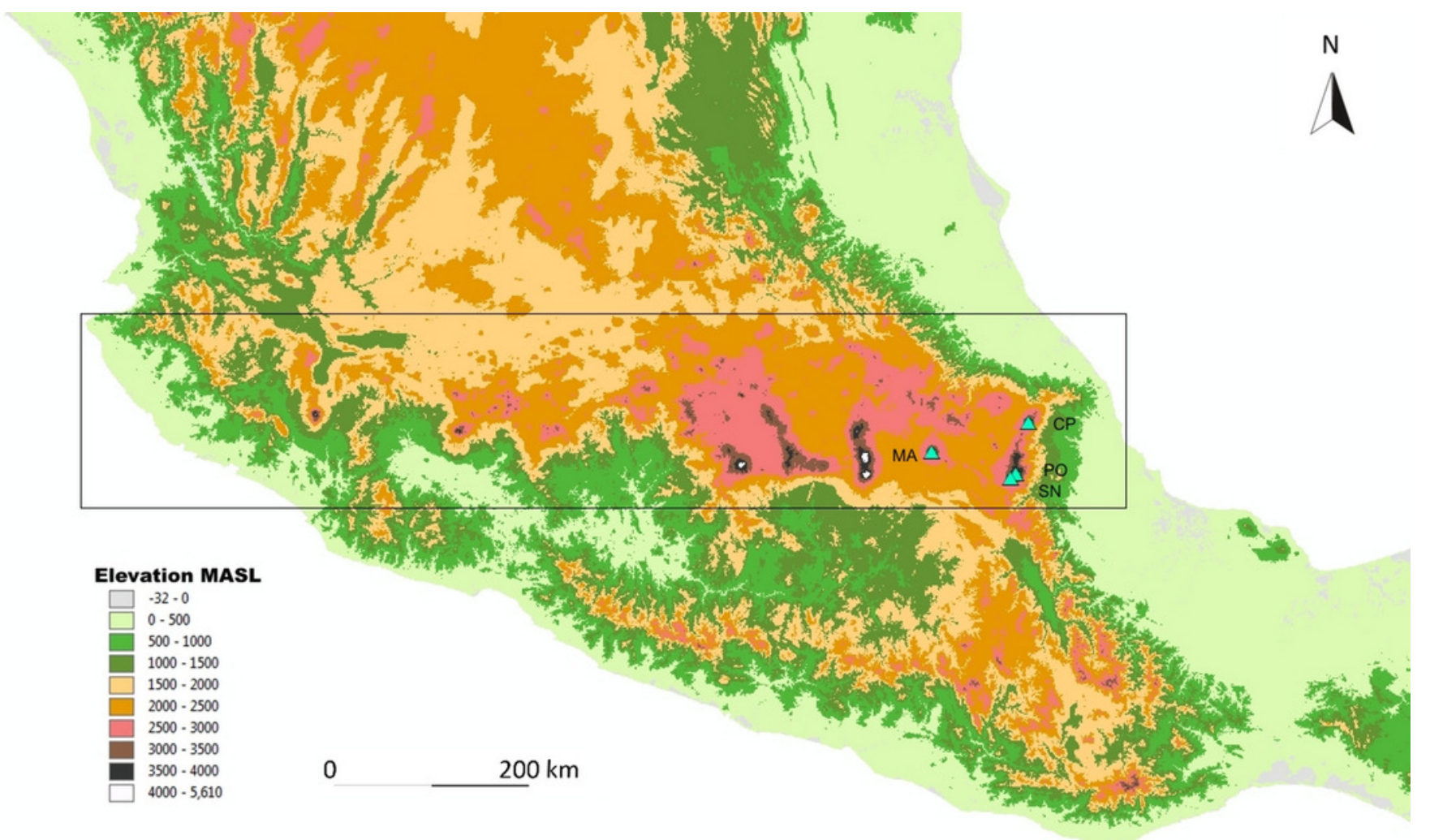


Figure 2

Alpha and gamma diversity of the four mountains

Results of alpha and gamma diversity for orders $q=0$ and $q=2$ (upper and lower value, respectively), and abundance for each sampling site. Values in the central square show gamma diversity of each mountain. Numbers below the square indicate abundances. (A) MALa Malinche, (B) CP - Cofre de Perote, (C) PO - Pico de Orizaba, (D) SN - Sierra Negra. W western leeward side, E - eastern windward side. Upper squares display values at $3400 \mathrm{MASL}$ and lower squares at $2700 \mathrm{MASL}$.

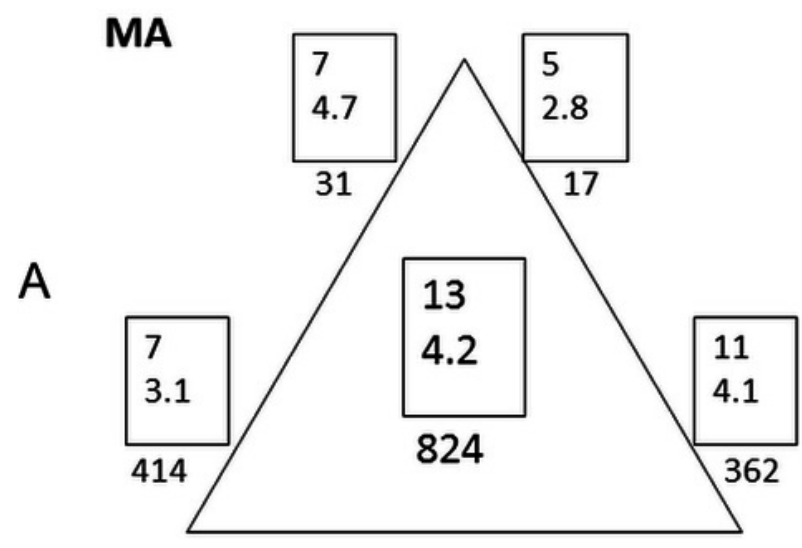

$\underline{3400 \mathrm{~m}}$
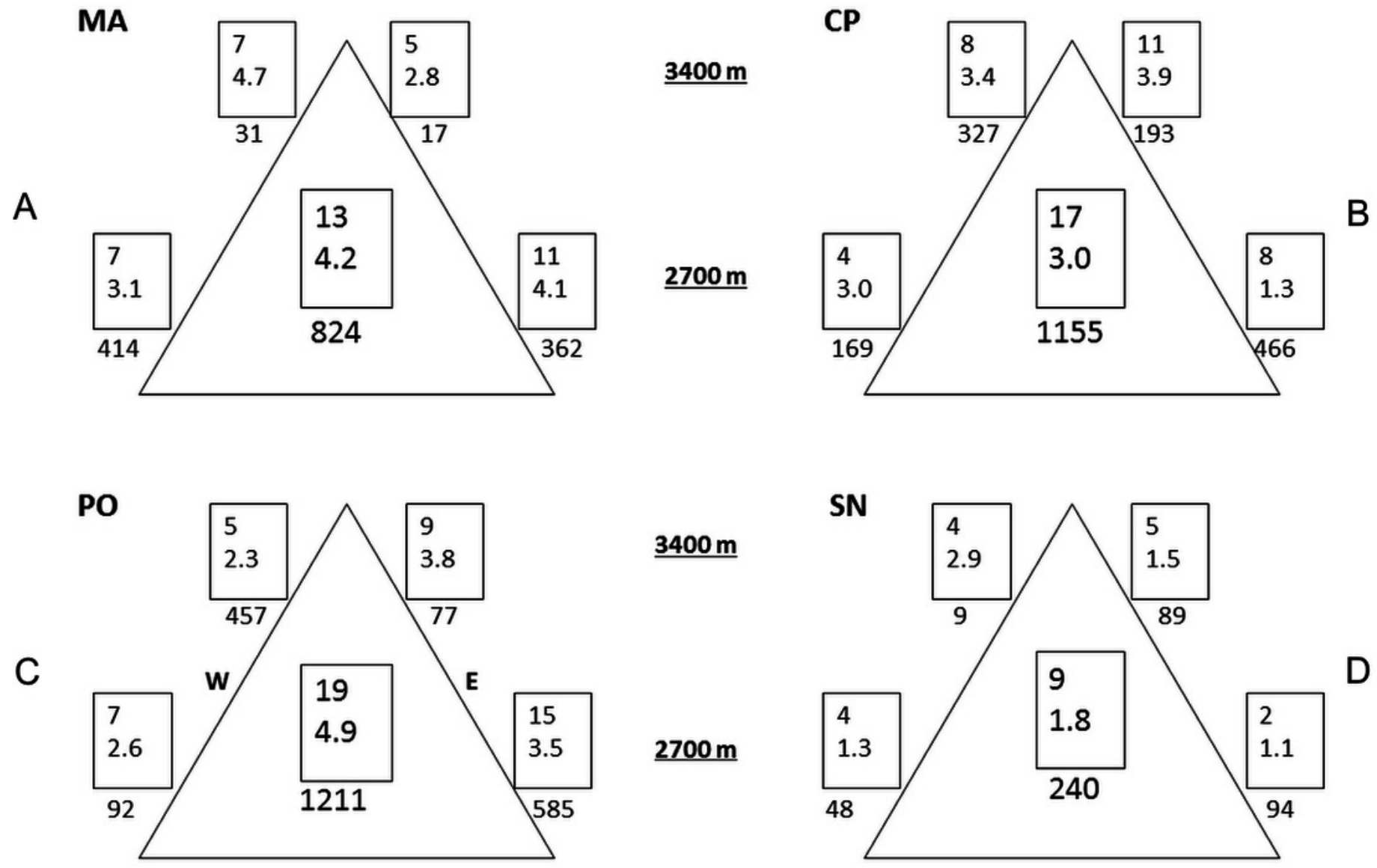

$3400 \mathrm{~m}$

$\underline{2700 m}$

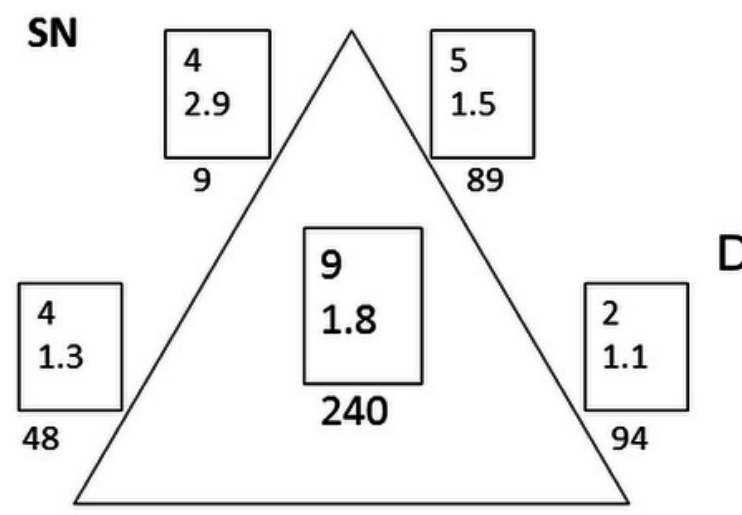


Figure 3

Compositional Similarity at the four mountains

Compositional Similarity ${ }^{~} \mathrm{CS}$ within and among sites ( $q=0$ upper value, $q=2$ lower value) at the four mountains: (A) MA- La Malinche, (B) CP - Cofre de Perote, (C) PO - Pico de Orizaba, (D) SN - Sierra Negra. Values inside the squares show CS among traps. Left squares -

Western leeward sides, right squares - Eastern windward sides. Upper squares display values at 3400 MASL and lower squares at 2700 MASL. Values without squares show the pairwise CS between sites, arrows indicate which pairs were compared.

MA
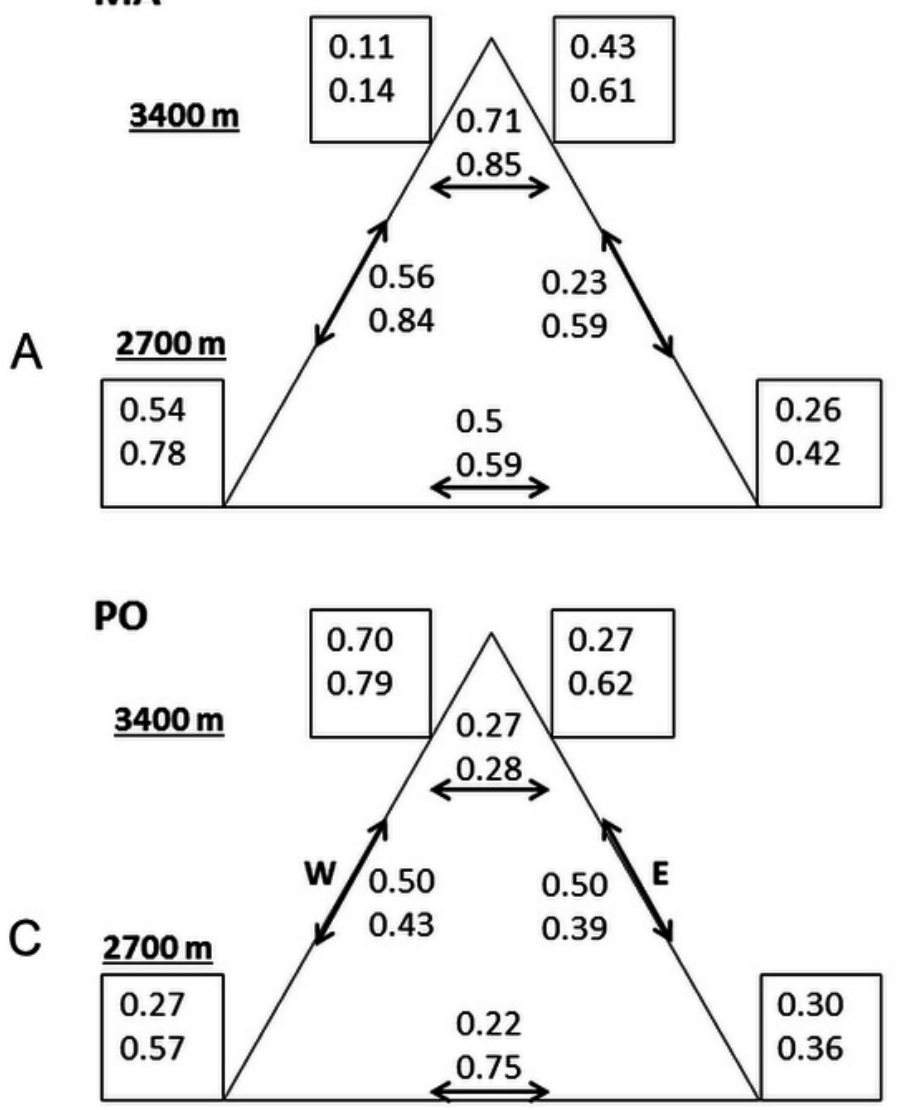
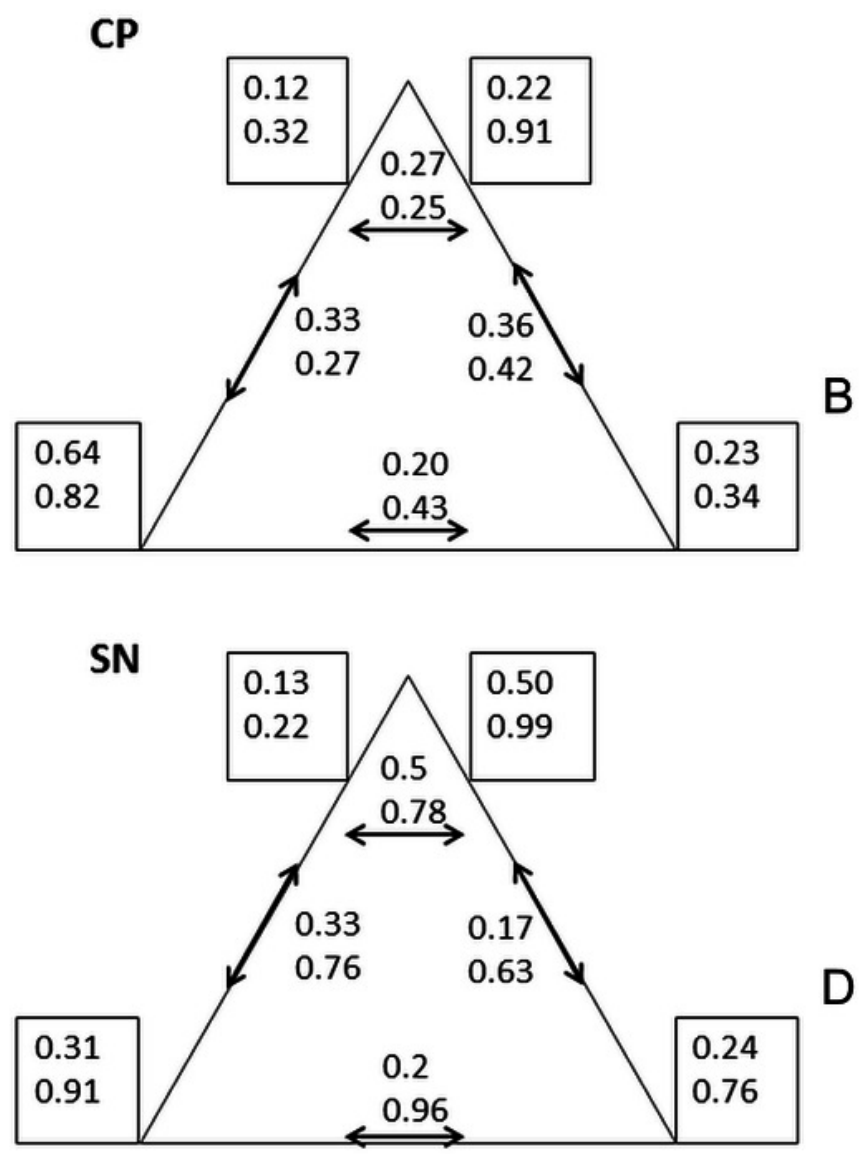
Figure 4

Compositional similarity between pairs of mountains in relation to its distances

Compositional similarity and distances between each pair of mountains, the upper value presents ${ }^{\circ} \mathrm{CS}$, the lower value ${ }^{2} \mathrm{CS}$ (Jaccard and Morisita-Horn compositional similarity, respectively). The table indicates CS-values when the most abundant species Onthophagus chevrolati chevrolati (with a mean relative abundance of 0.5 ), was excluded from the analysis (see text). MA - Malinche, CP - Cofre de Perote, PO - Pico de Orizaba, SN - Sierra Negra. Positions and distances based on GoogleEarth Images.

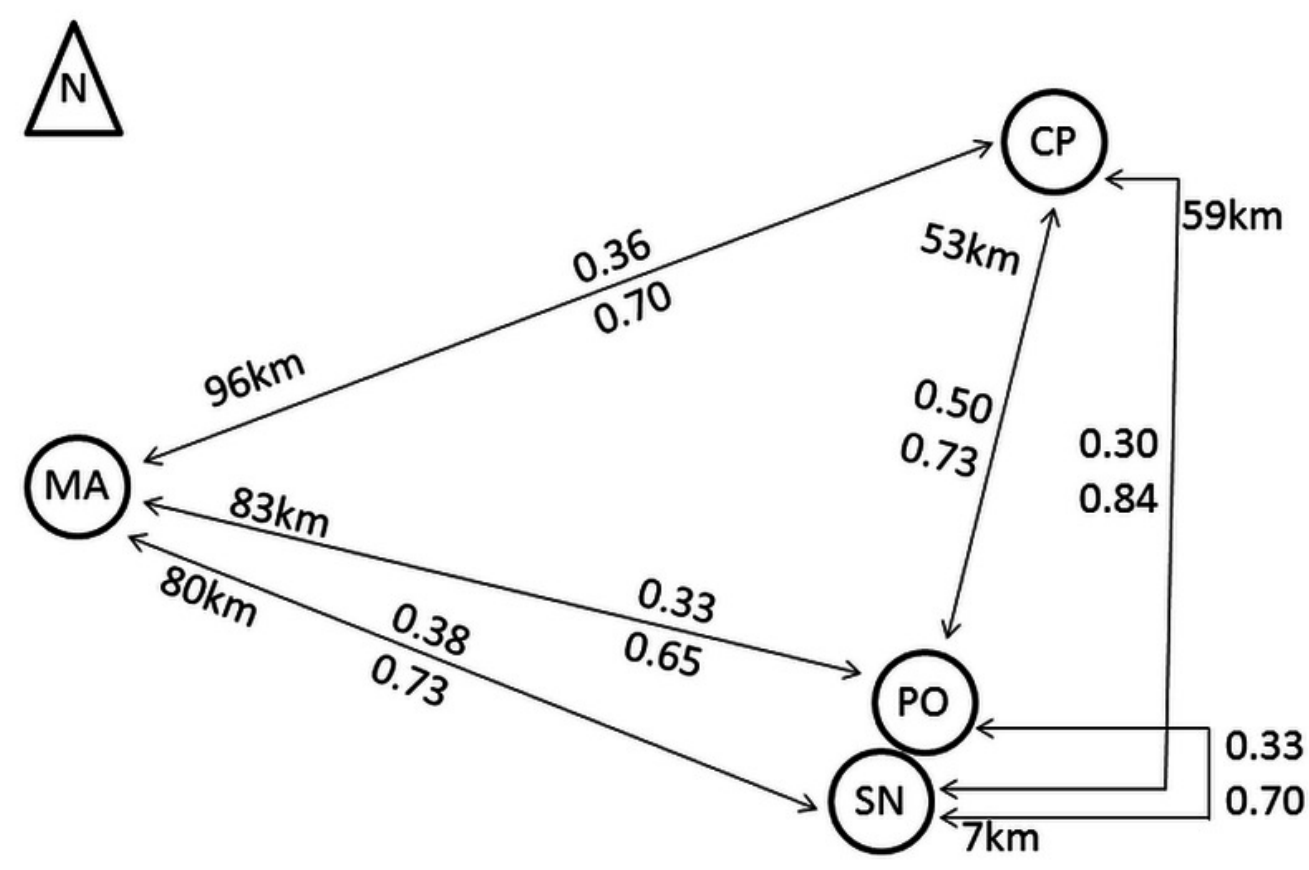

Table shows pairwise Compositional Similarity ${ }^{9} \mathrm{CS}$ between mountains when Onthophagus c. chevrolatiwas excluded from analysis.

\begin{tabular}{c|cccccc} 
Order & MA-CP & MA-PO & MA-SN & CP-PO & CP-SN & PO-SN \\
\hline${ }^{\circ} \mathrm{CS}$ & 0.33 & 0.30 & 0.33 & 0.48 & 0.26 & 0.30 \\
\cline { 2 - 7 }${ }^{2} \mathrm{CS}$ & 0.02 & 0.10 & 0.12 & 0.23 & 0.13 & 0.23
\end{tabular}

